\title{
Assessment of vitamin $\mathbf{G}$ status
}

\section{By R. E. Hughes, Department of Applied Biology, UWIST, Cardiff, Wales}

Vitamin $\mathrm{C}$ is $\mathrm{L}-\mathrm{xyloascorbic}$ acid (ascorbic acid, AA). Its first oxidation product is dehydroascorbic acid (dehydroAA) which also possesses vitamin $\mathrm{C}$ activity, possibly because of the ease with which many animal tissues can reduce it back to AA (Grimble \& Hughes, 1967). AA and dehydroAA may be referred to as 'total vitamin C'.

The determination of AA, or of AA and dehydroAA, is central to all accepted methods for the assessment of vitamin $C$ status. Two main methods (or modifications of them) are in current use. The more sensitive, but less specific, method is the one introduced in 1943 by Roe \& Kuether; the AA, after oxidation to dehydroAA, is condensed with 2,4-dinitrophenylhydrazine and the product treated with sulphuric acid to give a red colour, the intensity of which is measured photometrically (Roe \& Kuether, 1943; Räiha, 1958). This method, unless appropriately modified, gives a value for 'total vitamin $C$ ' as it includes any preformed dehydroAA. Small amounts of dehydroAA are probably present in plasma; because of its rapid biological reduction to $\mathrm{AA}$ and its short half-life at physiological conditions of $\mathrm{pH}$ and temperature, it is unlikely, however, to be present in living tissues in measurable amounts. It has been known for some years that certain tissues contain a dinitrophenylhydrazine-reacting substance other than AA or dehydroAA (Hughes, I956); this may introduce an appreciable error into vitamin $C$ levels determined by this method, particularly with samples taken during states of depletion or semi-depletion (Hodges, quoted by Brook, I973).

The second method is based on the reduction of an acidic solution of the redox dye 2,6-dichlorophenolindophenol by AA (Harris \& Ray, I935; Bessey, 1938). AA (but not dehydroAA (a non-reducing compound) is measured. This method also lacks specificity. However, many of the interfering substances (reductones, thiosulphates etc.) are unlikely to be present in animal tissues. Furthermore, by appropriately controlling the $\mathrm{pH}$ and the reaction time the specificity can be greatly increased and interference from glutathione and other sulphydryl compounds, virtually completely eliminated (Bland, Constable, Harris \& Hughes, 195 I ; Hughes, 1956). This method is simpler and probably more specific than the dinitrophenylhydrazine method and is the method of choice for many determinations; where low concentrations of vitamin $\mathrm{C}$ are being measured (as in the determination of leucocyte AA) the more sensitive dinitrophenylhydrazine method must be used.

The primary aim of any type of nutritional assessment is to obtain a measure either of the concentration of the nutrient in pre-selected 'key' tissues or of the 
magnitude of the body pool of the nutrient. Neither of these factors is easily measurable directly and both are beyond the bounds of practicability in terms of routine survey work. Secondary or indirect methods are therefore used, for example, the measurement of the nutrient (or its metabolites) in blood and urine or the study of biochemical systems in which the nutrient is involved. The methods used for the assessment of vitamin $\mathrm{C}$ status conform to this general pattern.

\section{Dietary surveys}

Presumptive evidence of a person's vitamin C status may be obtained by calculating or determining the dietary intake of the vitamin and comparing the value obtained with either the recommended daily allowance or with intakes known to produce specific degrees of tissue saturation. This may be done for individuals or, less satisfactorily, on a population basis. Allen, Brook \& Broadbent (1968), using the Food Consumption Tables (Ministry of Agriculture, Fisheries and Food, National Food Survey Committee, I $_{95}$ ), showed that in up to $10 \%$ of British households the mean daily vitamin $\mathrm{C}$ intake was permanently below the recommended $30 \mathrm{mg}$. The actual intake of vitamin $\mathrm{C}$ is probably considerably less than intakes calculated from food tables or food purchases; in a recent survey of the dietary habits of a group of nuns in South Wales chemical analysis of the food after cooking and serving gave AA contents significantly below those obtained by using the standard food tables and applying, whenever suggested, the appropriate corrections for preparation, cooking etc. (M. L. Burr, R. J. Hurley and R. E. Hughes, unpublished results). Similar findings were reported by Disselduff and Murphy (I 968). Dietary surveys are perhaps more a commentary on feeding habits than a measure of nutritional status.

\section{Tissue ascorbic acid concentrations}

The ideal method of assessing vitamin $\mathrm{C}$ status would be to measure not dietary intakes but actual tissue levels. Hodges and co-workers, in an extensive series of studies with human volunteers, have used labelled AA to obtain information about the physiology of the vitamin at the tissue level and particularly in scorbutic and near-scorbutic states (Hodges, Baker, Hood, Sauberlich \& March, I969; Hodges, Hood, Canham, Sauberlich \& Baker, 197I). These studies have provided us with much useful information about AA turnover rate, the size of the body pool of AA and its relationship to blood $A A$, and the extent to which massive doses of the vitamin are incorporated into the body pool. There are, however, obvious methodological difficulties that preclude the use of such techniques in any type of large-scale survey work.

Indirect attempts to reveal the vitamin C status of the tissues date from the midthirties when Harris and others introduced saturation and loading tests for the assessment of vitamin C status (Abbasy, Harris, Ray \& Marrach, 1935). Before the development of blood AA analysis the saturation test was widely accepted. A large dose of AA is given daily to the subject and the time lapse before AA appears in the urine is measured: the AA will appear in the urine when the tissues have been 
saturated. Subjects deficient in AA will have a longer 'saturation-period' than AAsufficient subjects.

Tests of this type are still widely used by clinicians who frequently regard them as diagnostic aids with a built-in therapeutic advantage. Loading and saturation tests are theoretically sound. There is evidence, however, that the results they produce cannot always be correlated with those of other established methods of vitamin $\mathrm{C}$ assessment; saturation and loading tests have little differential value at the lower levels of AA intake (Krebs, 1953). Three groups of factors may contribute to the emergence of discrepant results in saturation and loading tests: (a) poor absorption of the vitamin or the existence of a low 'absorption ceiling' may give a falsely high saturation period, particularly with elderly subjects; (b) transient or temporary hypersaturation may also prolong the saturation period (Penney \& Zilva, 1946; Hurley, Jones \& Hughes, I972); (c) determinations of urinary AA are frequently complicated by the presence of interfering substances (Hodges et al. 1969). Up to $50 \%$ of the indophenol dye-reducing capacity of urines from subjects with average intakes of vitamin $\mathrm{C}$ is contributed by compounds other than vitamin $\mathrm{C}$

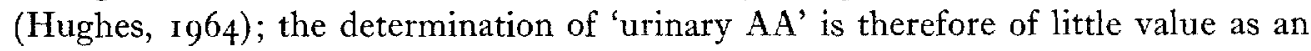
index to the status of the vitamin in the tissues of non-saturated subjects.

\section{Blood vitamin $C$}

Physiologically, blood is less remote from tissue metabolism than is urine and theoretically its value as an index to tissue nutrient levels should be correspondingly greater. A number of methodological difficulties, however, have militated against the widespread use of whole blood in this respect. The indophenol dye method is unsatisfactory for whole blood because of the conversion of AA to dehydroAA by oxygen liberated from the oxyhaemoglobin on addition of the protein precipitant; again, erythrocytes appear to contain an interfering substance that gives falsely high values with the dinitrophenylhydrazine method (R. E. I Hughes, unpublished results).

On the other hand, plasma levels of $\mathrm{AA}$ and of total vitamin $\mathrm{C}$ have been widely used as an index to vitamin $C$ status. Over a range of moderate intakes of AA there is a good correlation between the dietary intake and the plasma concentration of AA. This, however, is not entirely an advantage; unless the AA intake has been fairly constant over a prolonged period the plasma concentrations may be more closely related to dietary intake than to tissue levels. Despite this, plasma AA is frequently determined and the Interdepartmental Committee on Nutrition for National Defense (ICNND) recommendation that plasma levels below $\mathrm{I} \mathrm{mg} / \mathrm{l}$ are indicative of a state of deficiency (Interdepartmental Committee on Nutrition for National Defense, 1963), has found widespread acceptance.

The determination of vitamin $\mathrm{C}$ in the leucocytes or white blood cells is probably the method favoured by most investigators and is claimed by many workers to be the most useful index to tissue AA levels (Griffiths, Brocklehurst, Scott, Marks \& Blackley, 1967; Andrews \& Brook, I968); this claim has been recently challenged by Loh \& Wilson (197I). Most techniques are based on that of Denson \& Bowers (I96I). Leucocyte AA measurements are certainly technically more exacting than 
plasma studies and this probably accounts, at least in part, for the existence of discrepancies and inconsistencies, when the results of workers in different laboratories are compared (Griffiths, I 968). Provided that the determinations are accurately done, the leucocyte method has much in its favour: the fall in leucocyte AA during periods of deprivation corresponds to the calculated fall in the body pool size of AA and in guinea-pigs on controlled intakes of AA there is a significant correlation between leucocyte AA and tissue AA. On the other hand, the exact relationship between plasma $A A$ and leucocyte AA remains puzzling. Significant, positive correlations between the two values have been reported for different groups of subjects (Griffiths et al. I967; Loh \& Wilson, 197I). More recently, a correlation between plasma AA and leucocyte AA was reported to exist in elderly subjects but not in young ones (Bates, Hughes \& Hurley, 1972).

\section{Miscellaneous tests}

Other tests which have been used include an intradermal test (Rapaport 8 Miller, I939), a lingual test (Clark, Cheraskin, Ringsdorf \& Arnim, 1970) and measurements of salivary AA. None of these has found general acceptance. In a recent study no correlation was found between the results of the lingual test and the leucocyte and plasma AA levels; a highly significant correlation existed between salivary AA and leucocyte AA in males (irrespective of age) but not in females (Bates et al. 1972).

Theoretically, the most useful test would be a biochemical one based on the activity of a system in which AA has a clearly defined metabolic role. Tests of this type are essential to the practising nutritionist. An example is the use of the formiminoglutamic acid (FIGlu) technique for the assay of folic acid. Attempts to relate the urinary levels of metabolites of hydroxyproline and tyrosine to the involvement of $\mathrm{AA}$ in the metabolism of the two compounds and, therefore, to the tissue levels of AA have not yet been successful. However, more recent findings relating to the role of AA as a co-factor in a number of other biological hydroxylating systems (for example those involving $p$-hydroxyphenylpyruvate hydroxylase and $\gamma$-butyrobetaine hydroxylase) suggest a number of interesting possibilities in this direction (Barnes \& Kodicek, 1972). A valuable contribution to nutritional science would be the characterization of a biochemical system (such as one involving detoxication by microsomal hydroxylation) in which AA plays a co-factor role and which could be adapted for use as a test system to measure tissue AA levels. The substrate for such a test need not necessarily be a naturally-occurring one. It would, however, have to be non-toxic at the dose-level to be administered; AA would be a co-factor for its hydroxylation and the hydroxylated metabolite would be quantitatively excreted in the urine.

\section{Interpretation of blood AA levels}

Blood AA determinations have an obvious value in the diagnosis of scurvy. Scurvy, however, is a comparatively rare condition in Britain (Brook, 1973) and most blood AA concentrations are between the 'scorbutic level' and the 'saturation 
level'. The classical signs of scurvy are probably all attributable in the final analysis to defective formation of collagen. Recent evidence suggests that AA may have physiological involvements other than the maintenance of collagen formation. These 'extra-antiscorbutic' functions would presumably involve tissue levels of AA greater than those required to prevent scurvy. Fatigue, lassitude and depression have been associated with low tissue levels of vitamin $\mathrm{C}$ and they may appear some time before the clinical signs of frank scurvy (Brook, 1973). Suggested involvements of AA in areas such as iron absorption and cholesterol metabolism have been interpreted as indicating that variations in tissue $A A$ outside the usually accepted 'scorbutic' limit, may be of significance. If this is true, then blood AA studies over the whole physiological range could be of interest and possibly of value. But until these implied 'extra-antiscorbutic' functions are more fully characterized and quantitatively related to tissue concentrations of $\mathrm{AA}$, measurements of blood AA will continue to be of only limited value. They will indicate a person's AA status only with respect to tissue depletion and tissue saturation; the physiological significance of tissue levels greater than those required to prevent scurvy is currently unknown although there is an unproved assumption that tissue saturation is to be preferred to states of partial saturation.

The problems of interpretation in elderly subjects are still more complex. Elderly subjects have, in general, lower blood levels of AA than younger ones (Kirk \& Chieffi, 1953; Andrews \& Brook, 1966; Wilson \& Nolan, 1970) and some investigators have referred to the 'widespread ascorbic acid ... deficiency in elderly patients' (Griffiths, i 968 ). In a recent survey of an elderly population, some $40 \%$ of males aged 70 years and over had plasma ascorbic acid levels below $\mathrm{I} \mathrm{mg} / \mathrm{l}$, i.e. they were deficient according to the ICNND standard. However, visits to medical practitioners were no more frequent among the 'deficient' group than among the 'non-deficient' group (Burr, Elwood, Hole, Hurley \& Hughes, r973). Results of recent work have indicated that the ability to either abstract or retain AA or both is greater in metabolically-active tissues (e.g. young, growing ones) than in less 'active' ones and the negative correlation between AA concentrations and age could be an example of this (Hughes \& Jones, 197I; Williams \& Hughes, 1972). However, the comparison of the biochemical pattern of 'old' tissues with that of 'young' ones and the interpretation of any deviant 'old' patterns as abnormal ones, is scientifically inappropriate. It may even be argued that the elderly subject has, in the course of evolution, adapted his tissue metabolism to comparatively low levels of AA (or, conversely, that the low levels reflect a changed pattern of metabolism); if this is true, then supplementation with AA to raise 'elderly' levels to those of 'young' subjects would be an essentially negative action and could conceivably even have deleterious changes. Other factors such as smoking habits and sex may further complicate the picture and references to 'normal 'or 'optimal' blood levels of AA become somewhat meaningless.

Until the results of morbidity and mortality studies in elderly subjects vis-à-vis AA levels become available (supplemented perhaps by the results of longevity studies with guinea-pigs receiving different dietary intakes of the vitamin), no direct physiological significance can be confidently attributed to different blood 
AA levels. Certainly, the significance of the low blood levels in elderly subjects is far from clear and caution should be exercised in uncritically accepting that they necessarily reflect a deviant and undesirable pattern.

\section{REFERENCES}

Abbasy, M. A., Harris, L. J., Ray, S. N. \& Marrach, J. R. (1935). Lancet ii, I399.

Allen, R. J. L., Brook, M. \& Broadbent, S. R. (ig68), Br. F. Nutr. 22, 555.

Andrews, J. \& Brook, M. (1966). Lancet i, I350.

Andrews, J. \& Brook, M. (1968). Geront. clin. ro, 128.

Barnes, M. J. \& Kodicek, E. (I972). Vitams Horm. 30, $\mathbf{x}$.

Bates, J. F., Hughes, R. E. \& Hurlcy, R. J. (1972). Archs oral Biol. 17, I017.

Bessey, O. A. (1938). 7. biol. Chen. 126, 77 I.

Bland, M. N., Constable, B. J., Harris, L. J. \& Hughes, R. E. (195I), Proc. int. Congr. pure appl. Chem. (Food and Nutrition Section) XII, New York p. 155.

Brook, MI. (1973). In Nutritional Deficiencies in Modern Society p. 45 [A. N. Howard and I. M. Baird, editors]. London: Food Education Society.

Burr, M. L., Elwood, P. C., Hole, D. J., Hurley, R. J. \& Hughes, R. E. (1973). Am. F. clin. Nutr. (In the Press.)

Clark, J. W., Cheraskin, E., Ringsdorf, W. M. \& Arnim, S. S. (1970). Diet and the Periodontal Patient p. 23r. Springfield, Ill.: Thomas.

Denson, K. W. \& Bowers, E. F. (196r). Clin. Sci. 21, I 57.

Disselduff, M. M. \& Murphy, E. La C. (Ig68). In Vitamins and the Elderly p. 60 [A. N. Exton-Smith and D. L. Scott, editors.] Bristol: Wright.

Griffiths, L. L. (I968). In Vitamins and the Elderly p. 34 [A. N. Exton-Smith and D. L. Scott, editors]. Bristol: Wright.

Griffiths, L. L., Brocklehurst, J. C., Scott, D. L., Marks, J. \& Blackley, J. (I967). Geront. clin. 9, I.

Grimble, R. F. \& Hughes, R. E. (1967). Experientia 23, 362 .

Harris, I. J. \& Ray, S. (1935). Lancet 228, 7 I.

Hodges, R. E., Baker, E. M., Hood, J., Sauberlich, H. W. \& March, S. C. (1969). Am. J. clin. Nutr. 22, 535 .

Hodges, R. E., Hood, J., Canham, J. E., Sauberlich, H. E. \& Baket, E. M. (I971). Am. F. clin. Nutr. 24, 432 .

Hughes, R. E. (1956). Biochem. 7. 64, 203.

Hughes, R. E. (1964). Analyst, Lond. 89, 6 I8.

Hughes, R. E. \& Jones, P. R. (1971). Br. Y. Nutr. 25, 77.

Hurley, R. J., Jones, P. R. \& Hughes, R. E. (1972). Nutr. Metab. 14, I 36.

Interdepartmental Committee on Nutrition for National Defense (1963). Manual for Nutrition Surveys and ed. Bethesda, Md: National Institute of Health.

Kirk, J. E. \& Chieffi, M. (r953). F. Geront. 8, zor.

Krebs, H. A. (1953). Proc. Nutr. Soc. 12, 237.

Loh, H. S. \& Wilson, C. W. M. (1971). Br. med. F. 3, 733.

Penney, J. R. \& Zilva, S. S. (I946). Biochem. F. 40, 695.

Ministry of Agriculture, Fisheries and Food, National Food Survey Committee (I965). Domestic Food Consumption and Expenditure (1963). London: H.M. Stationery Office.

Räiha, N. (1958). Acta physiol. scand. 45, suppl. I55, 24.

Rapaport, H. G. \& Miller, S. (1939). F. Pediat. 15, 503.

Roe, J. H. \& Kuether, C. A. (1943). \%. biol. Chem. 147, 399.

Wilson, C. W. M. \& Nolan, C. (1970). Ir. Y. med. Sci. 3, 345.

Williams, Rh. S. \& Hughes, R. E. (1972). Br. F. Nutr. 28, I67. 